\title{
The Moderation of Financial Literacy on the Relationship Between Individual Factors and Risky Investment Intention
}

\author{
Selim Aren ${ }^{1} \&$ Sibel Dinç Aydemir ${ }^{2}$ \\ ${ }^{1}$ Faculty of Economics and Administrative Sciences, Yildiz Technical University, İstanbul, Turkey \\ ${ }^{2}$ Faculty of Business Administration, Gebze Technical University, Kocaeli, Turkey \\ Correspondence: Sibel Dinç Aydemir, Faculty of Business Administration, Gebze Technical University, Gebze, \\ Kocaeli, Turkey. Tel: 90-262-605-1431. E-mail: saydemir@gyte.edu.tr
}

Received: March 20, 2015

Accepted: April 1, 2015

Online Published: May 25, 2015

doi:10.5539/ibr.v8n6p17

URL: http://dx.doi.org/10.5539/ibr.v8n6p17

\begin{abstract}
In this paper, the authors aim to manifest the effects of individual factors such as risk averseness in general, locus of control on risky investment intention. At the same time, this study intends to examine whether financial literacy moderates the relationship between risk averseness in general, locus of control and risky investment intention. The data set comprised of 112 participants through survey method. We fulfilled hierarchical regression in order to examine the hypothesized relationships. Accordingly, results showed that risk averseness in general had a significant and negative impact on risky investment behavior. Yet, this study provided no evidence of locus of control as a factor in predicting risky investment intention. Last but not least, it was found that financial literacy moderated these relationships. In other words, financial literacy changed the relationship between risk averseness in general, locus of control and risky investment intention.
\end{abstract}

Keywords: risk averseness in general, locus of control, financial literacy, risky investment intention, financial behavior

\section{Introduction}

Although sometimes shifted their lenses according to paradigms, understanding financial behavior has been a contunial focus by the researchers. Financial intermediaries and policymakers also have been interested in this issue in terms of microeconomic (i.e., demand for their products) and macroeceonomic (i.e., savings or investments) perspectives respectively.

Reasonating with the classical finance paradigm, many research has focused on the demographic or socio-economic factors in explaining the financial behavior (e.g., Bajtelsmit \& Bernasek, 1996; Grable \& Lytton, 1998; Powel \& Ansic, 1997; Dwyer et al., 2002; Hallahan et al., 2004; Grable \& Joo, 2004; Roszkowski \& Grable, 2005; Jianakoplos \& Bernasek, 2006; Selcuk et al., 2010; Lutfi, 2010; Adhikari \& O’leary, 2011; Ansong \& Gyensare, 2012; Charness \& Gneezy, 2012; Halko et al., 2012; Gong \& Yang, 2012; Lai \& Tam, 2012; Kamas \& Preston, 2012; Larkin et al., 2013; Duasa \& Yusof, 2013). In ceteris paribus conditions (i.e., everyone is rationale and the sum of the deviations from rational behavior is zero, the probabilities are stochastic), this focus has been reasonable. Yet, the new behavioral finance paradigm approachs financial behavior from another perspective. Although the proponents of this paradigm have claimed that they do not negate the tenets of classical finance theory, it has been necessary to change researchers' lenses according to new extended assumptions (i.e., everyone is not rational, the deviations are systematic and the probabilities are subjective). This has encouraged finance researchers to discuss deep-rooted concepts in psychology in financial context. Then, the emphasis has shifted on the pyschological or attitudinal factors which could encompass any subjectivity.

At the same time, financial literacy has been another phenomenon of interest (See Aren \& Aydemir, 2014, for a review). We know more about the important role of financial knowledge on most financial behaviors (e.g., Bayer, Bernheim, \& Scholz, 1996; Hilgert, Hogarth, \& Beverly, 2003; Dhar \& Zhu, 2006; Servon \& Kaestner, 2008; Guiso \& Jappelli, 2008; Van Rooij, Lusardi, \& Alessi, 2007; Dvorak \& Hanley, 2010; Lusardi \& Mitchell, 2007a; Al-Tamimi \& Bin Kalli, 2009; Shahrabani, 2012; Mandell \& Klein, 2009; Müller \& Weber, 2010; Smith, Finke, \& Huston, 2011; Van Rooij, Lusardi, \& Alessi, 2011; Cole, Sampson, \& Zia, 2011; Perry \& Morris, 2005; Ludlum et al., 2012; Robb \& Woodyard, 2011; Robb, 2011; Wachira \& Kihiu, 2012; Lachanse \& Tang, 2012). However, we 
know less about its effect on risky investment intention specifically. What's more, little effort has been devoted to examining the indirect effect of financial literacy (i.e., as a moderator variable) on financial behavior since the extant literature has focused on its direct effect.

We also know more about the relation between risk taking attitude and general or financial behavior (e.g., Weber \& Milliman, 1997; Grable \& Lytton, 1998; Sjöberg, 1998; Weber et al., 2002; Roszkowski et al., 2005; Siegrist et al., 2005; Selcuk et al., 2010). It is generally expected that a risk averse individual would also refrain from any risky behavior. Actually, the associated relationship is not so undemanding. For example, Weber et al. (2002) showed that people are not consistently risk averse or risk seekers in all situations, implying that risk taking depends on the corresponding domain. Nevertheless, we expect that an individual's risk averseness in general life would show consistency with his or her financial risk avoidance as well. However, there must be another factor which makes this obvious relationship between them differentiated. Concordantly, we propose that financial literacy would make diverge some people avoiding risks in general but taking financial risks from those avoiding risks both in general and also in financial context.

Briefly, our study contributes to the literature in three ways. First, it incorporates both some individual factors and also financial literacy -strong resource in financial decision making- into financial behavior context. Risk averseness in general reflects an individual's general attitude into risk taking while locus of control represents an individual's enduring trait. Second, it detects both direct and also indirect or systematic influences (i.e., moderation effect) of financial literacy on the relationships between these factors and risky investment intention. Third, our results regarding financial literacy highlight a new research question of whether another indirect effect type (i.e., moderated mediation) could occur.

To these ends, we provide the extant literature and hence ground our hypotheses first. Then, we present the establishment of variables and and the procedure of sampling and analyses which we employed. Lastly, we discuss the theoretical and practical implications, limitations and new research areas of our study.

\section{Literature Review}

\subsection{Risk Averseness in General and Risky Investment Intention}

Risk averseness in general is an attitude reflecting to which degree an individual generally avoids to take risks in his or her life. According to theory of reasoned action (Ajzen \& Fishbein, 1977) and planned behavior (Ajzen, 1991), attitudes and subjective norms identify the likelihood of the ocurrence of behavior by influencing that behavior intention. This attitude may have a notable role on why people opt for certain products or avoid from others.

Regarding taking risk which is deemed as one of entrepreneurial traits, there exist two approaches in the management literature. First approach is that risk taking is an personality trait while the second one is that risk taking is a changing state of mind depending on the varying circumstances (McCarty, 2000). In a study of Schoemaker (1993), it is stated that an individual's intrinsic risk attitude may differ from his or her observed risk taking. As an explanation for this divergency, the author suggest different problem structuring, information processing ways, value functions, beliefs and context and process factors of individuals. Moreover, Weber et al. (2002) provide evidence of that risk taking level of individuals is domain specific. In other words, individuals are not consistently risk averse or risk seekers in all domains. This attitude varies according to the content domain. This study shows similarity with that of Sitkin and Weingart (1995). They explain the relationship between risk perception and risky decision making in manner that risk perception mediates the relationship between the problem framing, outcome history and risky decision making.

Nevertheless, there are lot of studies focused on the relationship between risk taking and risky behavior (e.g., Weber \& Milliman, 1997; Grable \& Lytton, 1998; Sjöberg, 1998; Weber et al., 2002; Roszkowski et al., 2005; Siegrist et al., 2005; Selcuk et al., 2010). In these studies, it is generally expected that a risk averse individual would also refrain from any risky behavior.

On the other hand, Van Rooij et al. (2007, p. 23) propose that risk averseness in addition to financial literacy should be included into understanding financial behavior since people's risk averseness level could make differences on their financial behavior.

We expect individuals' risk averseness in general to influence risky investment intention in a negative direction. An individual having no willingness to take risks in general could also avoid undertaking risky investments. Thus, twe hypothesize that;

H1: Risk averseness in general has a negative impact on risky investment intention. 


\subsection{Locus of Control and Risky Investment Intention}

According to Rotter (1966), the effect of a reinforcement on a behavior could show divergency between individuals in terms of the degree to which an individual discerns that this reward stems from his or her behavior. Accordingly, if any reinforcement or reward is perceived by the individuals as a result of their actions, these individuals are deemed as having internal locus of control. Yet, if any reinforcement or reward is discerned by the individuals as a result of outside forces such as luck, chance, destiny, these individuals are called as having external locus of control. Starting from this, in predicting the nature of learning processes, this variable is hypothesized to be significant and to show consistent differences between individuals. Within this context, Internal and external locus of control as a personality variable has been used in lots of studies.

The research focused on the determinants of locus of control shows that age has a significant and positive effect on this personality factor (See, Ganesan et al., 2003). When the people get older, they tend to have internal locus of control. Prior research examining the role of locus of control on the decision making setting is abounding. In a study, it is found that managers with higher internal locus of control tend to tap into group consultative decision making. As an explanation, the author suggests that these managers have enough confidence and belief in their competence and this belief makes the inclusion of other people in the process easy.

Locus of control is deemed as an entrepreneurial trait in the literature (e.g., Chelariu et al., 2008; Schjoedt \& Shaver, 2012; Al-Habib, 2012; Jain \& Ali, 2013). Namely, entrepreneurs have internal locus of control. At the same time, risk taking is considered as another personality trait of entrepreneurs (e.g., Al-Habib, 2012, Kreiser et al., 2013). Thus, locus of control may be related to risk taking. Indeed, there is a growing body of research relating locus of control variable to risky behavior. Baron (1968) refers to a positive relationship between external locus of control and conservative risk taking behavior. Carpentier et al. (2014) report that attitudes, social norms and locus of control make a significant contribution to predicting risky behavior (i.e., risky driving). In an earlier study, it is found that locus of control mediates the relationship between perception and risky behavior, in health domain (Crisp \& Barber, 1995).

These findings enable locus of control as an individual factor to be discussed in behavioral finance setting. In their study integrating demographics, socio-economic and psychologic factors into one model, Grable and Joo (2000) conclude that locus of control, financial knowledge aand gender are predictors of financial risk tolerance. Also, when compared to financial knowledge and gender, locus of control has gerater contribution to explaining financial risk tolerance. Additionally, Perry and Morris (2005) show that locus of control have both direct and indirect effect on responsible financial behavior. As for indirect effect, locus of control moderates the relationship between financial knowledge and responsible financial behavior. Accordingly, individual with high internal locus of control would have more benefits of their financial knowledge on their financial management.

When we consider the relation of locus of control as a personality variable to risk taking, we anticipate it to have impact on risky investment intention. So, the next hypothesis is;

$\mathrm{H} 2$ : (External) locus of control has a negative impact on risky investment intention.

\subsection{Financial Literacy and Risky Investment Intention}

Financial literacy can be defined as the degree to which an individual know about the fundamental financial concepts and the functioning of the financial markets. Servon and Kaestner (2008, p. 273) describe financial literacy as a person's ability to understand and make use of financial concepts.

Financial literacy has been phenomenon of interest in the recent past since how much people know about financially helps greatly in explaining financial decision or behavior. With the arrival of market deregulation (Mandell \& Klein, 2009) and new social security reforms in all over the world (Van Rooij et al., 2011), people have been more active and responsible agents for their financial planning. Hence, these developments have highlighted the importance of financial literacy. With this motive, this phenomenon has been extensively examined by the researchers in the literature (see Aren \& Aydemir, 2014, for a review). Most research indicates that individuals have the deficiency of financial literacy which would assist them to make wise financial decisions (e.g., Guiso \& Jappelli, 2008; Al-Tamimi \& Bin Kalli, 2009; Shahrabani, 2012).

There is a growing body of research examining the determinants of financial literacy. In this respect, some studies describe the role of demographics such as gender, education, experience, income, etc. On being financially literate (e.g., Guiso \& Jappelli, 2008; Lusardi \& Mitchell, 2008; Al-Tamimi \& Bin Kalli, 2009; Ansong \& Gyensare, 2012; Müller \& Weber, 2010). Briefly, it can be said that financial illiteracy has been more seen among women, those with little work experience, those under age 30 (e.g., Chen \& Volpe, 1998; Lusardi et al., 2010). While those people working in banking and finance sector, having both higher income and 
educational level are more financially literate (Al-Tamimi \& Bin Kalli, 2009).

According to valuable research arguing the role of financial literacy on financial decision or behavior, financial illiteracy has been considered as the reason for portfolio underdiversification (Guiso \& Jappelli, 2008), inadequate stock participation (Van Rooij, Lusardi, \& Alessi, 2011), unpreparedness for post-retirement times (Lusardi \& Mitchell, 2007b), wealth unaccumulation (Van Rooij, Alessi, \& Lusardi, 2012), being unable to make personal contributions (Van Rooij, Kool, \& Prast, 2007; Dvorak \& Hanley, 2010) and allocation changes (Dvorak and Hanley, 2010) for retirement plans, poor investment decisions (Al-Tamimi \& Bin Kalli, 2009), no intention to control personal budget (Sharahbani, 2012), financial dissatisfaction (Yoong, See, \& Baronovich, 2012), irresponsible financial management behavior (Perry \& Morris, 2005; Ludlum et al., 2012), poor financial practice behavior (Robb \& Woodyard, 2011), irresponsible credit card usage of college students (Robb, 2011), inability to make informed financial decisions (Chen \& Volpe, 1998), unimproved household financial management behavior (Hilgerth, Hogarth, \& Beverly, 2003), preponderantly purchasing of actively managed funds in spite of their high expenses (Müller \& Weber, 2010).

Lusardi and Mitchell (2007a/b) indicate that financially illiterate households are less likely to plan for retirement and to accumulate wealth. Moreover, Van Rooij et al. (2011) provide evidence of financial illiteracy as the reason for inadequate stock participation. In other words, people with lower financial knowledge are less likely to attend in stock market which is known as risky investing in the literature. These people have deficiency of the needed financial knowledge which could direct them to take advantage of financial markets and portfolio diversification (Guiso \& Jappelli, 2008).

In the view of such research, we anticipate that financial literacy of individuals has impact on risky investment intention. The more they know about financial concepts and the operating of financial markets, the more they have intention to make risky investments. So, the new hypothesis here is;

\section{H3: Financial literacy has a positive impact on risky investment intention.}

Along with these main effects, we also expect indirect effects between forementioned variables. In their paper, Baron and Kenny (1986) define a moderator variable in this way:

"In general terms, a moderator is a qualitative or quantitative variable that affects the direction and/or strength of the relation between an independent or predictor variable and a dependent or or criterion variable" (p. 1174).

In our study, we predict that the relationship between individual characteristics and risky investment intention would diversify according to individuals' financial literacy level. As the financial knowledge being a strong resource for individuals to make investment, we expect that financial literacy would shift the strength of these relationships.

As we mentioned before, individuals avoiding taking risks in general are less likely to have a risky investment intention. Yet, there may be differences between an individual's intrinsic risk attitudes and observed risk taking due to the various factors such as context and process factors and information processing (Schoemaker, 1993). Accordingly, more financially literate individuals would avoid undertaking risky investment less although they tend to avoid generally taking risks more in their life. More financial knowledge would shift their risky investment perception by shaping problem structuring or information processing of the relevant investment decision. Or, risk averseness level of an individual would change in the financial domain as Weber et al. (2002) suggest. Accordingly, the next hypothesis is;

H4: Financial literacy moderates the relationship between risk averseness in general and risky investment intention.

Similarly, when the individuals have an internal (external) locus of control, they tend to have more (less) financial risk tolerance (Grable \& Joo, 2000) and hence they have more (less) risky investment intention. With more financial knowledge, these internal (external) individuals would tend to invest in risky investments alternatives more (less) than they do. Hence, the next hypothesis here is;

H5: Financial literacy moderates the relationship between locus of control and risky investment intention.

\section{Research Method}

\subsection{Measurement of Variables}

In order to test the above hypotheses, a questionnaire measuring all constructs by using five point likert type scales ranging from 1 (strongly disagree) to 5 (strongly agree) was used.

Although the existence of various types to measure financial literacy of individuals, resent researchers design 
two modules in order to measure financial literacy of individuals (Van Rooij et al., 2011). According to these modules, financial literacy can be examined under two components, both of which are basic and advanced literacy. Basic literacy measures individuals' awareness about the fundamental financial topics such as numeracy, compounding interest, inflation, time value of money and money illusion while advanced literacy aims to measure the operating of financial markets, the difference between a bond and a stock, having idea of diversifying risk and the relationship between bond prices and interest rates. This measurement comprised of five basic and eleven advanced literacy questions. We employ this scale in this study. An index was calculated through the true answers of questions, by assigning one point to each correct answer. Respondents were also allowed to choose "don't know" option as well.

For locus of control construct, we modified the scale in Perry and Morris (2005) into five point likert type. This measure consisted of seven items. Higher and lower scores on this scale represent external and internal locus of control respectively. In measuring the risk averseness in general, seven-item scale combining the items of Donthu and Gilliland (1996), Burton et al. (1998) was employed. Higher risk averseness scores are related to avoiding risk taking more.

Risky investment intention scale comprised of the modified four items of both Putrevu et al. (1994) and Dodds et al. (1991). Higher scores on this scale represent having higher risky investment intention.

\subsection{Sampling}

Our study sample comprised of 112 individuals through convenience sampling method. The sample encompasses mostly postgraduates and personnel in a university. We did not include undergraduates even if they are above 18 and more (sufficient for being able to invest) on the grounds that they are not financially independent and hence not familiar with the idea of managing their finance and making an investment. Similarly, postgraduates being financially dependent still were not allowed to take part in the study for.

Sampling descriptive characteristics showed that nearly 61 percent of the participants were male; most of them were postgraduates (70 of 112 participants). The people aged between 20-30 (31-40) accounted for almost 51 (33) percent of the study sample. Nearly 52 (46) percent of the participants constituted single (married) people. 58 percent of the sample comprised of the people whose income level is between Turkish Liras 2001-5000. There were fifteen (twenty nine) individuals having an income level between TL 5001-10.000 (2000 and less).

\subsection{Measure Validity and Reliability}

In our measurement design, we have modified and combined the items of some scales (i.e., risk averseness in general and risky investment intention). Hence, we employed exploratory factor analysis in order to see to which extent these items would accumulate on the same factors. Firstly, KMO value shows that our study sample is adequate for factor analysis. Principal component analysis has extracted three factors. Based on the varimax rotation method, the factor loadings of items and Cronbach's alpha values of factors in the final analysis can be seen on Table 1.

Meanwhile, financial literacy scale is not subject to factor analysis as an observed variable which is calculated through the true answers of participants.

Table 1. Validity and reliability of unobserved measures

\begin{tabular}{|c|c|c|c|}
\hline KMO Value & 0,80 & & \\
\hline Items & Risky Investment Intention & Risk Averseness in General & Locus of Control \\
\hline N1 & 0.872 & & \\
\hline $\mathrm{N} 2$ & 0.931 & & \\
\hline N3 & 0.920 & & \\
\hline N4 & 0.877 & & \\
\hline $\mathrm{R} 1$ & & 0.633 & \\
\hline R2 & & 0.709 & \\
\hline R3 & & 0.588 & \\
\hline R4 & & 0.818 & \\
\hline R5 & & 0.649 & \\
\hline
\end{tabular}




\begin{tabular}{lll}
\hline R7 & 0.782 & \\
L1 & & 0.493 \\
L2 & 0.760 \\
L3 & 0.715 \\
L6 & 0.838 \\
L7 & 0.749 \\
\hline Cronbach's Alphas & 0.838 & 0.797 \\
\hline
\end{tabular}

Table 2 exhibits means, standard deviations and correlations amongst variables. Accordingly, it can be said that risk averseness in general is in significant relation to basic and advanced financial literacy and risky investment intention. Yet, locus of control seems not to have any significant association with any variable. Basic and advanced financial literacy correlate to each other significantly and positively. Last, risk averseness in general and advanced financial literacy significantly have a negative and positive relation to risky investment intention respectively.

Table 2. Means, standard deviations, and correlations among variables

\begin{tabular}{|c|c|c|c|c|c|c|}
\hline Variables & Mean & S.D. & 1 & 2 & 3 & 4 \\
\hline 1. Risk Averseness & 3.47 & 0.77 & & & & \\
\hline 2. Locus of Control & 2.12 & 0.72 & 0.077 & & & \\
\hline 3. Basic Financial Literacy & 2.96 & 1.36 & $-0.221^{*}$ & -0.014 & & \\
\hline 4. Advanced Fin. Literacy & 4.66 & 3.27 & $-0.253^{* *}$ & -0.072 & $0.578^{* *}$ & \\
\hline 5. Risky investment intention & 2.31 & 0.92 & $-0.493^{* *}$ & -0.007 & 0.057 & $0.202^{*}$ \\
\hline
\end{tabular}

Note. $* \mathrm{p}<0.05 ; * * \mathrm{p}<0.01$

\subsection{Analyses and Results}

In order to test our hypotheses, we fulfilled hierarchical regression through IBM SPSS Statistics 22. For two reasons, we preferred to include advanced financial literacy into equations. First, bivariate (zero-order) correlations between variables highlighted that there is a strong relationship between basic and advanced financial literacy (r: 0.578). Second, the advanced literacy rather than the basic one is found to significantly relate to risky investment intention. Besides, Van Rooij et al. (2007) claim that the relationship between financial literacy and stock ownership becomes stronger for advanced literacy rather than the basic one. When we considered that advanced literacy questions measure financial knowledge regarding as (1) what the stocks and the bonds represent, (2) the difference between them, (3) the relationship between interest rates and bond prices, (4) functioning of the capital markets, this relation is not surprising. Therefore, we incorporated the advanced financial literacy into our regression equations.

As illustrated in Table 3, we made two hierarchical regressions in two steps and conducted the analyses with mean-centered variables in order that all predictor variables have a meaningful zero point (Geiser, 2013, p. 38). Herewith, this enables the interpretation of the interaction effects without causing the effects to be inflated (Hair et al., 2014, p. 260).

In the first step of the former model in which risky investment intention as a dependent variable, risk averseness in general and advanced financial literacy as independent variables take place, risk averseness in general was found to be a significant strong predictor of our criterion variable. Thus, H1 was supported by our results. Yet, the effect of advanced financial literacy on risky investment intention was insignificant. In the second step, the product term of risk averseness and advanced financial literacy was included into equation. Interaction term is significant $(\mathrm{p}<0.01)$. Furthermore, the interaction term accounted for a significant increase in $\mathrm{R}$ square $\left(\Delta \mathrm{R}^{2}=0.049, \mathrm{p}<0.01\right)$. It denoted that the interaction between risk averseness in general and advanced financial literacy level explained a significant part of the variation in risky investment intention beyond which risk averseness and advanced financial literacy level explained together. Besides, this interaction term means more. When the advanced financial literacy level is increased or decreased by one standard deviation unit, the 
relationship between risk averseness in general and risky investment intention is expected to shift by the size of -0.222 . Consequently, $\mathrm{H} 4$ was supported in our study.

In the first step of the latter model in which risky investment intention as a dependent variable, locus of control and advanced financial literacy as independent variables take place, locus of control was found to have no impact on risky investment intention individually. It means that $\mathrm{H} 2$ was not supported. However, advanced financial literacy had a significant influence on our criterion variable $(\mathrm{p}<0.05)$. In the second step, the interaction term of locus of control and advanced financial literacy was included into the model. And consequently, it was found that the interaction term was significant $(\mathrm{p}<0.05)$ and that the interaction term explained a significant part of the variation in risky investment intention beyond locus of control and advanced financial literacy level explained together $(\Delta \mathrm{R} 2=0.039, \mathrm{p}<0.05)$. The significant interaction term here means that one standard deviation unit increase or decrease in advanced financial literacy level is expected to change the relationship between locus of control and risky investment intention by the size of -0.198 . Thus, our hypothesis (H5) suggesting that financial literacy moderates the relationship between locus of control and risky investment intention was supported. Table 3 summarizes all regression results.

Table 3. Hierarchical regression results

\begin{tabular}{|c|c|c|}
\hline \multirow[t]{2}{*}{ Variables } & \multicolumn{2}{|c|}{ Risky Investment Intention } \\
\hline & Sta. Betas & $\Delta \mathrm{R}^{2}$ \\
\hline \multicolumn{3}{|l|}{ Step 1 in Model 1} \\
\hline Risk Averseness & $-0.472 * *$ & \\
\hline Advanced Financial Literacy & 0.082 & \\
\hline \multicolumn{3}{|l|}{ Step 2 in Model 1} \\
\hline Risk Averseness & $-0.446 * *$ & \\
\hline Advanced Financial Literacy & 0.105 & \\
\hline Risk Averseness*Adv. Financial Literacy & $-0.222 * *$ & $0.049 * *$ \\
\hline \multicolumn{3}{|l|}{ Step 1 in Model 2} \\
\hline Locus of Control & 0.008 & \\
\hline Advanced Financial Literacy & $0.212 *$ & \\
\hline \multicolumn{3}{|l|}{ Step 2 in Model 2} \\
\hline Locus of Control & 0.000 & \\
\hline Advanced Financial Literacy & $0.208^{*}$ & \\
\hline LoC* Advanced Financial Literacy & $-0.198 *$ & $0.039 *$ \\
\hline
\end{tabular}

Advanced financial literacy was found to be insignificant in the model in which risk averseness and advanced financial literacy predicted risky investment intention while it is significant in that model in which locus of control and advanced literacy explained the criterion variable. Thus, we could not support H3 directly. But this contrariness arouses curiosity in that how financial literacy having a significant zero order correlation $(\mathrm{r}=0.202)$ with risky investment intention became insignificant in the model in which risk averseness as the second predictor variable (financial literacy as the other predictor) are expected to explain risky investment intention. The effect of advanced financial literacy on risky investment intention may probably be conveyed through risk averseness. In other words, insignificant beta coefficient of financial literacy in Model 1 may refer to risk averseness in general as a mediator variable conveying the effect of financial literacy on risky investment intention. After risk averseness included into equation, financial literacy's effect may have been insignificant. In that case, moderated mediation effect (see Preacher et al. (2007), for detail) is also questionable. Figure 1 makes this type of relationship more visible. According to this figure, financial literacy has impact on behavior intention. Additionally, risk averseness in general mediates this relationship. What's more, financial literacy moderates the relationship between risk averseness in general and risky investment intention. We can explain the case in this manner. Since we did not hypothesize this moderated mediation relationship priorly, we could not provide any 
evidence of this. After all, it is more appropriate to examine this kind of relationship through structural equation modeling.

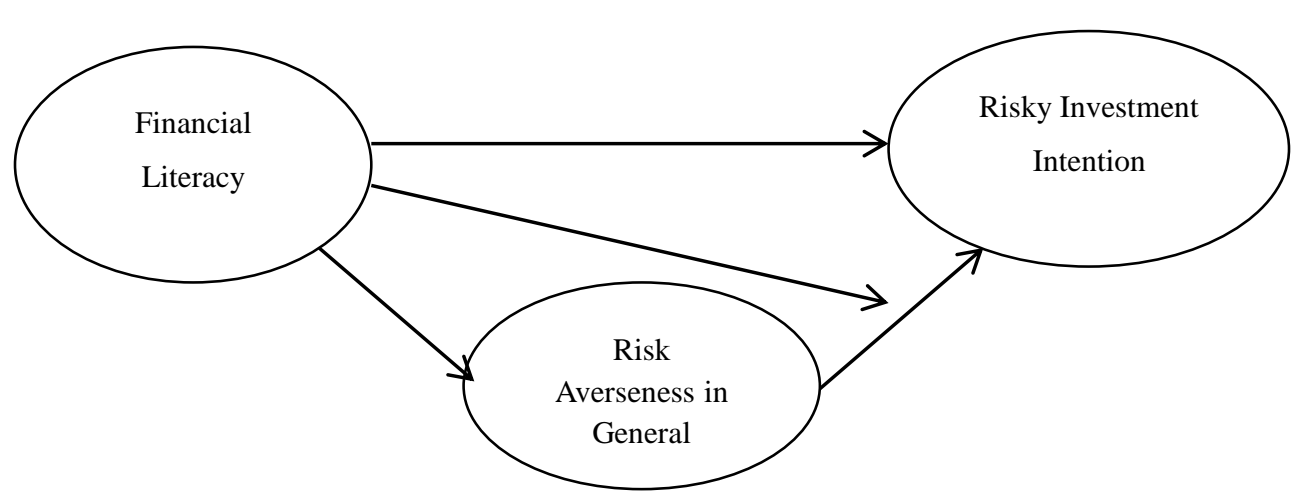

Figure 1. Exhibition of the moderated mediation type

\section{Discussion and Conclusion}

\subsection{Theoretical and Practical Implications}

In this study, it is emprically demonstrated that risk averseness in general and financial literacy level had impact on the risky investment behavior represented by behavior intention. This means that a general attitude reflecting our view of avoiding taking risks in our general life seems to have influence on our financial behavior. This is important to the finance literature in terms of the manifestation of the relationship between a general risk taking and financial risk taking. Although proposed by Schoemaker (1993) that the instrinsic risk taking could diverge from the observed risk taking, in the view of main effects, our study shows that our general risk taking attitude does not differ in a financial risk taking setting.

Particularly advanced financial knowledge which the individuals have constitutes a strong advantage in front of their financial behavior (especially risky investment behavior). Our study results show consistency with prior research manifesting the importance of financial literacy on financial behavior. Moreover, the most important finding in our study is that financial literacy moderates the relationship between some individual factors (i.e., risk averseness in general and locus of control) and risky investment intention. When the financial literacy is higher, then the negative relationship between risk averseness and risky investment intention is stronger. The people who generally avoid taking risk in their life more are less likely to engage in risky investments. Yet, these risk averse people in general will avoid risky investments more if they have higher advanced financial literacy. This finding can be explained by the people's limited information processing capability. More financial information does not lead those generally risk-averse people to have higher risky investment intention. Besides, this finding strengthens the role of financial literacy more than that demonstrated by the prior research since there exist no study suggesting the indirect effect of financial literacy on financial behavior.

Unfortunately, our study does not support the hypothesis that locus of control has impact on risky investment intention. Yet, financial literacy interacting with locus of control moderates this relationship. In other words, higher advanced financial literacy are expected to change this relationship in a negative direction. External individuals with higher financial literacy are less likely to have risky investment intention than those externals with lower financial literacy level. It can be said that more information directs people with external control to have more personal responsibility with their risky financial behavior by making them more realistic about the risky investments.

These findings regarding the presence of financial literacy's moderating effect are more fruitful for those policymakers and financial intermediaries by indicating that the increase in financial literacy level of people could have an important influence on their investments. When equipped with higher financial literacy, their attitudes to finacial risk taking or their intentions to invest in risky assets would differ.

Last but not least, the adverse results regarding as financial literacy would give the idea of another indirect effect (i.e. moderated mediation) prospect which is mentioned in the results section. These results asking a new research question can be considered as another contribution of this study.

All in all, this study provides notable insights regarding showing whether the probable risk takers (those who 
don't avoid taking risks in general and those who have internal locus of control) could also take risks in the financial context. This paper also contributes to previous research on financial literacy by manifesting its indirect effect beyond the direct one and by questioning the other indirect effect type (i.e., moderated mediation) which the financial literacy has on the financial behavior.

\subsection{Limitations}

As in any study, there are some limitations in our study as well. Definitely, the larger sample size would enable us to attain more generalizable results. Secondly, using convenience sampling method, our sample may have some deficiencies in terms of variability and representability of the population.

\subsection{Suggestions}

We emprically articulate the manifestion of financial literacy as a moderator variable. Yet, it may have some other sistematic influences on the above posited relationships. As we illustrated in Figure 1, first, we suggest researchers consider a moderated mediation effect into their research based on structural equation modelling. Second, it is better to replicate this research with a larger sample size through SEM in order to validate our results. Third, in future, the role of other individual factors such as emotional intelligence representing emotional abilities and personality traits on financial behavior could be investigated.

\section{References}

Adhikari, B. K., \& O'leary, V. (2011). Gender differences in risk aversion: A developing nation's case. Journal of Personal Finance, 10(2), 122-147.

Ajzen, I. (1991). The theory of planned behavior. Organizational Behavior and Human Decision Processes, 50, 179-211. http://dx.doi.org/10.1016/0749-5978(91)90020-T

Ajzen, I., \& Fishbein, M. (1977). Attitude-behavior relations: Theoretical analysis and review of empirical research. Psychological Bulletin, 84, 888-918. http://dx.doi.org/10.1037/0033-2909.84.5.888

Al-Habib, M. (2012). Identifying the traits of entrepreneurs in a university setting: An empirical examination of Saudi Arabian University students. International Business \& Economics Research Journal, 11(9), 1019-1028.

Al-Tamimi, Hussein, A. H., \& Bin Kalli, Al A. (2009). Financial literacy and investment decisions of UAE investors. Journal of Risk Finance, 10(5), 500-516. http://dx.doi.org/10.1108/15265940911001402

Ansong, A., \& Gyensare, M. A. (2012). Determinants of university working-students' financial literacy at the University of Cape Coast, Ghana. International Journal of Business and Management, 7(9), 126-133. http://dx.doi.org/10.5539/ijbm.v7n9p126

Aren, S., \& Aydemir, S. D. (2014). A literature review on financial literacy. Journal of Financial Researches and Studies, 5(11), 33-49. http://dx.doi.org/10.14784/jfrs.2014117326

Bajtelsmit, V. L., \& Bernasek, A. (1996). Why do women invest differently than men? Financial Counseling and Planning, 7, 1-10.

Baron, R. A. (1968). Authoritarianism, locus of control and risk taking. Journal of Psychology: Interdisciplinary and Applied, 68(1), 141-143. http://dx.doi.org/10.1080/00223980.1968.10544138

Baron, R. M., \& Kenny, D. A. (1986). The moderator-mediator variable distinction in psychological research: Conceptual, strategic, and statistical considerations. Journal of Personality and Social Psychologhy, 51(6), 1173-1182. http://dx.doi.org/10.1037/0022-3514.51.6.1173

Bayer, P. J., Bernheim, B. D., \& Scholz, J. K. (1996). The effects of financial education in the workplace: Evidence from a survey of employers. National Bureau of Economic Research, NBER Working Paper Series, Working Paper 5655, pp. 1-29.

Burton, S., Lichtenstein, D. R., Netemeyer, R. G., \& Garretson, J. A. (1998). A scale for measuring attitude toward private label products and an examination of its psychological and behavioral correlates. Journal of The Academy of Marketing Science, 26(4), 293-306. http://dx.doi.org/10.1177/0092070398264003

Carpentier, A., Brijs, K., Declercq, K., Brijs, T., Daniels, S., \& Wets, G. (2014). The effect of family climate on risky driving of young novices: The moderating role of attitude and locus of control. Accident Analysis and Prevention, 73, 53-64. http://dx.doi.org/10.1016/j.aap.2014.08.005

Chelariu, C., Brashear, T. G., Osmonbekov, T., \& Zait, A. (2008). Entrepreneurial propensity in a transition economy: Exploring micro-level and meso-level cultural antecedents. Journal of Business \& Industrial 
Marketing, 23(6), 405-415. http://dx.doi.org/10.1108/08858620810894454

Chen, H., \& Volpe, R. P. (1998). An analysis of personal financial literacy among college students. Financial Services Review, 7(2), 107-128. http://dx.doi.org/10.1016/S1057-0810(99)80006-7

Cole, S., Sampson, T., \& Zia, B. (2011). Prices or knowledge? What drives demand for financial services in $\begin{array}{lllll}\text { emerging } & \text { Journal of }\end{array}$ http://dx.doi.org/10.1111/j.1540-6261.2011.01696.x

Crisp, B. R., \& Barber, J. G. (1995). The effect of locus of control on the association between risk perception and sexual risk-taking. Personality and Individual Differences, 19(6), 841-845. http://dx.doi.org/10.1016/S0191-8869(95)00117-4

Dhar, R., \& Zhu, N. (2006). Up close and personal: Investor sophistication and the disposition effect. Management Science, 52(5), 726-740. http://dx.doi.org/10.1287/mnsc.1040.0473

Dodds, W. B., Monroe, K. B., \& Grewal, D. (1991). Effects of price, brand, and store information on buyers' product evaluations. Journal of Marketing Research, 28(August), 307-319. http://dx.doi.org/10.2307/3172866

Donthu, N., \& Gilliand, D. (1996). Observations: The infomercial shopper. Journal of Advertising Research, 36(2), 69-76.

Duasa, J., \& Yusof, S. A. (2013). Determinants of risk tolerance on financial asset ownership: A case of Malaysia. International Journal of Business and Society, 14(1), 1-16.

Dvorak, T., \& Hanley, H. (2010). Financial literacy and the design of retirement plans. Journal of Socio-Economics, 39, 645-652. http://dx.doi.org/10.1016/j.socec.2010.06.013

Dwyer, P. D., Gilkeson, J. H., \& List, J. A. (2002). Gender differences in revealed risk taking: evidence from mutual fund investors. Economics Letters, 76, 151-158. http://dx.doi.org/10.1016/S0165-1765(02)00045-9

Ganesan, R., Kaur, D., Maheshwari, R. C., \& Stapathy, S. (2003). Demographic correlates of locus of control and perceived ladder of success: A study on women entrepreneurs. International Journal of Entrepreneurship, 7, 1-16.

Geiser, C. (2013). Data Analysis with Mplus. Newyork: Guilford Press.

Gong, B., \& Yang, C. (2012). Gender differences in risk attitude: Field experiments on the matrilineal mosuo and the patriarchal yi. Journal of Economic Behavior \& Organization, 83, 59-65. http://dx.doi.org/10.1016/j.jebo.2011.06.010

Grable, J. E., \& Joo, S. (2000). A cross-disciplinary examination of financial risk tolerance. Consumer Interests Annual, 46, 151-157.

Grable, J. E., \& Joo, S. (2004). Environmental and biopsychosocial factors associated with financial risk tolerance. Financial Counseling and Planning, 15(1), 73-82.

Grable, J. E., \& Lytton, R. H. (1998). Investor risk tolerance: Testing the efficacy of demographics as differentiating and classifying factors. Financial Counseling and Planning, 9(1), 61-74.

Guiso, L., \& Jappelli, T. (2008). Financial literacy and protfolio diversification. European University Institute, Department of Economics, Working Paper ECO 2008/31, pp. 1-36.

Hair, J. F., Hult, G. T. M., Ringle, C. M., \& Sarstedt, M. (2014). A Primer on Partial Least Squares Structural Equation Modeling (PLS-SEM). Newyork: SAGE.

Halko, M. L., Kaustia, M., \& Alanko, E. (2012). The gender effect in risky asset holdings. Journal of Economic Behavior \& Organization, 83, 66-81. http://dx.doi.org/10.1016/j.jebo.2011.06.011

Hallahan, T. A., Faff, R. W., \& McKenzie, M. D. (2004). An empirical investigation of personal financial risk tolerance. Financial Services Review, 13, 57-78.

Hilgerth, M. A., Hogarth, J. M., \& Beverly, S. G. (2003). Household financial management: The connection between knowledge and behavior. Federal Reserve Bulletin, 89, 309-322.

Jain, R., \& Ali, S. W. (2013). A review of facilitators, barriers, and gateways to entrepreneurship: Directions for future research. South Asian Journal of Management, 20(3), 122-163.

Jianakoplos, N. A., \& Bernasek, A. (2006). Financial risk taking by age, and birth cohort. Southern Economic Journal, 72(4), 981-1001. http://dx.doi.org/10.2307/20111864 
Kamas, L., \& Preston, A. (2012). The importance of being confident: Gender, career choice, and willingness to $\begin{array}{llllll}\text { compete. Journal of Economic Behavior \& Organization, 83, } & \text { 82-97. }\end{array}$ http://dx.doi.org/10.1016/j.jebo.2011.06.013

Kreiser, P. M., Marino, L. D., Kuratko, D. F., \& Weaver, K. M. (2013). Dissaggregating entrepreneurial orientation: The non-linear impact of innovativeness, proactiveness, and risk-taking on SME performance. Small Business Economics, 40, 273-291. http://dx.doi.org/10.1007/s11187-012-9460-x

Lachance, M., \& Tang, N. (2012). Financial advice and trust. Financial Services Review, 21, 209-226.

Lai, P., \& Tam, K. (2012). Gender discrepancy's impact on perceived risk and investment decision: A review of financial practitioners behavior in Hong Kong, China. Journal of Advances Research in Management, 1(5), 27-37.

Larkin, C., Lucey, B. M., \& Mulholland, M. (2013). Risk tolerance and demographic characteristics: Preliminary Irish evidence. Financial Services Review, 22, 77-91.

Ludlum, M., Tilker, K., Ritter, D., Cowart, T., Xu, W., \& Smith, B. C. (2012). Financial literacy and credit cards: A multi campus survey. International Journal of Business and Social Science, 3(7), 25-33.

Lusardi, A., \& Mitchell, O. S. (2007a). Baby boomer retirement security: The roles of planning, financial literacy, and housing wealth. Journal of Monetary Economics, 54, 205-224. http://dx.doi.org/10.1016/j.jmoneco.2006.12.001

Lusardi, A., \& Mitchell, O. S. (2007b). Financial literacy and retirement preparedness: Evidence and implications for financial education. Business Economics, 42(1), 35-44. http://dx.doi.org/10.2145/20070104

Lusardi, A., \& Mitchell, O. S. (2008). Planning and financial literacy: How do women fare? National Bureau of Economic Research, NBER Working Paper Series, Working Paper 13750, pp. 1-10.

Lusardi, A., Mitchell, O. S., \& Curto, V. (2010). Financial literacy among the young. Journal of Consumer Affairs, 44(2), 358-380. http://dx.doi.org/10.1111/j.1745-6606.2010.01173.x

Lutfi. (2010). The relationship between demographic factors and investment decision in Surabaya. Journal of Economics, Business and Accountancy Ventura, 13(3), 213-224.

Mandell, L., \& Klein, L. S. (2009). The impact of financial literacy education on subsequent financial behavior. Journal of Financial Counseling and Planning, 20(1), 15-24.

McCarty, B. (2000). Researching the dynamics of risk-taking and social learning: An exploratory study of Irish entrepreneurs. Irish Marketing Review, 13(1), 46-60.

Müller, S., \& Weber, M. (2010 April). Financial literacy and mutual fund investments: Who buys actively managed funds. Schmalenbach Business Review, 62, 126-153.

Perry, V. G., \& Morris, M. D. (2005). Who is in control? The role of self-perception, knowledge and income in explaining consumer financial behavior. Journal of Consumer Affairs, 39(2), 299-313. http://dx.doi.org/10.1111/j.1745-6606.2005.00016.x

Powell, M., \& Ansic, D. (1997). Gender differences in risk behaviour in financial decision-making: An $\begin{array}{lllll}\text { experimental analysis. Journal of Economic Psychology, 18, 605-628. } & \text {. }\end{array}$ http://dx.doi.org/10.1016/S0167-4870(97)00026-3

Preacher, K. J., Rucker, D. D., \& Hayes, A. F. (2007). Addressing moderated mediation hypotheses: Theory, methods, and prescriptions. Multivariate Behavioral Research, 42(1), 185-227. http://dx.doi.org/10.1080/00273170701341316

Putrevu, S., \& Lord, K. R. (1994). Comparative and noncomparative advertising: Attitudinal effects under cognitive and affective involvement conditions. Journal of Advertising, 23(June), 77-90. http://dx.doi.org/10.1080/00913367.1994.10673443

Robb, C. A. (2011). Financial knowledge and credit card behavior of college students. Journal of Family and Economic Issues, 32, 690-698. http://dx.doi.org/10.1007/s10834-011-9259-y

Robb, C. A., \& Woodyard, A. S. (2011). Financial knowledge and best practice behavior. Journal of Financial Counseling and Planning, 22(1), 60-70.

Roszkowski, M. J., \& Grable, J. E. (2005). Estimating risk tolerance: The degree of accuracy and the paramorphic representations of the estimate. Financial Counseling and Planning, 16(2), 29-47. 
Roszkowski, M. J., Davey, G., \& Grable, J. E. (2005). Insights from psychology and pyschometrics on measuring risk tolerance. Journal of Financial Planning, 66-77.

Rotter, J. B. (1966). Generalized expectancies for internal versus external control of reinforcement (pp. 1-28). Psychological Monographs: General and Applied, Whole No: 609.

Schjoedt, L., \& Shaver, K. G. (2012). Development and validation of a locus of control scale for the $\begin{array}{lllll}\text { entrepreneurship } \quad \text { domain. } & \text { Small Business }\end{array}$ http://dx.doi.org/10.1007/s11187-011-9357-0

Schoemaker, P. J. H. (1993). Determinants of risk- taking: Behavioral and economic views. Journal of Risk and Uncertainty, 6, 49-73. http://dx.doi.org/10.1007/BF01065350

Selcuk, E., Altinoklar, A., \& Aydin, G. (2010). Financial risk tolerance: Scale development and analysis of determinants. Journal of American Academy of Business, 15(2), 89-97.

Servon, L. J., \& Kaestner, R. (2008). Consumer financial literacy and the impact of online banking on the financial behavior of lower-income bank customers. Journal of Consumer Affairs, 42(2), 271-305. http://dx.doi.org/10.1111/j.1745-6606.2008.00108.x

Shahrabani, S. (2012). The effect of financial literacy and emotions on intent to control personal budget: A study among 1sraeli college students. International Journal of Economic Finance, 4(9), 156-163. http://dx.doi.org/10.5539/ijef.v4n9p156

Siegrist, M., Gutscher, H., \& Earle, T. C. (2005). Perception of risk: The influence of general trust and general confidence. Journal of Risk Research, 8(2), 145-156. http://dx.doi.org/10.1080/1366987032000105315

Sitkin, S. B., \& Weingart, L. R. (1995). Determinants of risky decision-making behavior: A test of the mediating role of risk perceptions and propensity. Academy of Management Journal, 38(6), 1573-1592. http://dx.doi.org/10.2307/256844

Smith, H., Finke, M. S., \& Huston, S. J. (2011). The impact of financial sophistication on adjustable rate mortgage ownership. Journal of Financial Counseling and Planning, 22(2), 3-15.

Van Rooij, M., Kool, C. J. M., \& Prast, H. M. (2007). Risk-return preferences in the pension domain: Are people able to choose? Journal of Public Economics, 91, 701-722. http://dx.doi.org/10.1016/j.jpubeco.2006.08.003

Van Rooij, M., Lusardi, A., \& Alessi, R. (2011). Financial literacy and stock market participation. Journal of Financial Economics, 101, 449-472. http://dx.doi.org/10.1016/j.jfineco.2011.03.006

Van Rooij, M., Lusardi, A., \& Alessi, R. (2012). Financial literacy, retirement planning and household wealth. Economic Journal, 122(May), 449-478. http://dx.doi.org/10.1111/j.1468-0297.2012.02501.x

Van Rooij, M., Lusardi, A., \& Alessi, R. (2007). Financial literacy and stock market participation. National Bureau of Economic Research, Working Paper 13565, pp. 1-46.

Wachira, M. I., \& Kihiu, E. N. (2012). Impact of financial literacy on access to financial services in Kenya. International Journal of Business and Social Science, 3(19), 42-50.

Weber, E. U., \& Milliman, R. A. (1997). Perceived risk attitudes: Relating risk perception to risky choice. Management Science, 43(2),123-144. http://dx.doi.org/10.1287/mnsc.43.2.123

Weber, E. U., Blais, A., \& Betz, E. N. (2002). A domain-specific risk- attitude scale: Measuring risk perceptions and risk behaviors. Journal of Behavioral Decision Making, 15(4), 263-290. http://dx.doi.org/10.1002/bdm.414

Yoong, F. J., See, B. L., \& Baronovich, D. (2012). Financial literacy key to retirement planning in Malaysia. Journal of Management and Sustainability, 2(1), 75-86. http://dx.doi.org/10.5539/jms.v2n1p75

\section{Copyrights}

Copyright for this article is retained by the author(s), with first publication rights granted to the journal.

This is an open-access article distributed under the terms and conditions of the Creative Commons Attribution license (http://creativecommons.org/licenses/by/3.0/). 